\title{
Laboratory and numerical based analysis of floating sand columns in clayey soil
}

\author{
S. Naseer ${ }^{1 *} \mathbb{C}$, M. Sarfraz Faiz ${ }^{1}$ S. |qbal ${ }^{2}$ and S. M. Jamil ${ }^{1}$
}

*Correspondence:

snaseer.ms14@nice.nust.

edu.pk

${ }^{1}$ Department

of Geotechnical Engineering,

National University

of Sciences and Technology

(NUST), Islamabad, Pakistan

Full list of author information

is available at the end of the

article

\begin{abstract}
The inclusion of sand columns results in enhancing the bearing capacity of clayey soil, increase the rate of consolidation, presentation of liquefaction in loose sandy soils and provide lateral resistance against the horizontal movement. This research aims at investigating the effects of floating columns in clayey soil with silty deposits by developing small scale laboratory models. The effects of sand columns on soils of different shear strengths, slenderness ratio (L/D) of columns were investigated. Group effect was also investigated by varying spacing between the columns. Experimental results were compared with the numerical analysis results. A 15-noded triangular mesh was generated using a finite element tool PLAXIS 2D. Finite element analysis was performed using Mohr's Coulomb's criterion considering undrained analysis for soft clayey soil and drained analysis for sand columns. It was concluded that the sand columns can significantly increase the ultimate loading capacity of soft soils. Results show that critical length for floating column ranges from 4 to 5.5 times the diameter of the column, beyond which bulging occurs and loading capacity decreased. The effect of group was also investigated and observed that with high spacing between the sand columns, the group efficiency decreased. The axial capacity of sand columns decreases while increasing spacing between the columns.
\end{abstract}

Keywords: Sand columns, Bearing capacity, Shear strength, Floating columns

\section{Introduction}

The sand compaction piles (SCP) is a frequently used method for speedy improvement of soft clayey soils, especially in underwater conditions, such as that which exists in the land reclamation project. In regions where land is readily available, SCPs are likely to be a much more cost-effective option for ground improvement than chemical methods such as jet grouting and cement mixing. Several studies have been conducted by different researchers to investigate the behavior of stone columns using various analysis techniques, e.g. two-dimensional (2D) plane strain Tan et al. [26] or axisymmetric Ambily and Gandhi [3] and three-dimensional (3D) modelling Kadhim and Fouad [15], Killeen and McCabe [16]. In most of the cases, either the Mohr-Coulomb (MC) or HS models have been used to represent the behavior of both the granular column material and the treated soil (e.g. Killeen and McCabe [16]). Sexton and McCabe [24] were among the first to use a model incorporating viscous effects with an application to stone columns.

Aboshi et al. [1] outlined the development of the SCP method as follows: The first method of driving in the casing was by hammering in 1957. This method is still in use

(c) The Author(s) 2019. This article is distributed under the terms of the Creative Commons Attribution 4.0 International License (http://creativecommons.org/licenses/by/4.0/), which permits unrestricted use, distribution, and reproduction in any medium, provided you give appropriate credit to the original author(s) and the source, provide a link to the Creative Commons license, and indicate if changes were made. 
in certain places Bouckovalas and Giannaros [9]. Various experimental studies were conducted to predict the behavior of sand columns by different researchers Juran and Guermazi [13], Juran and Riccobono [14], Muir Wood et al. [19], Sivakumar et al. [25], Ayadat and Hanna [5], Black et al. [8]. Both single and group columns up to four columns in each group were tested with surrounding soft soils either with model foundation or in typical triaxial cells.

Juran and Riccobono [14], Sivakumar et al. [25], Black et al. [8] conducted small scale laboratory testing on model sand columns in the triaxial testing machine. The drainage conditions and loading rate was controlled while shearing of samples to establish undrained conditions. Few tests were conducted with slow loading rate to generate drained conditions. The behavior of granular column reinforced clay was also investigated by performing finite element analysis Baumann and Bauer [7], Alamgir et al. [2], Murugesan and Rajagopal [20].

Gustaf et al. [12] studied the behavior of the clay soil improved with stone columns and performed finite element (FE) analyses using PLAXIS 2D to assess the Young's modulus of the improved ground. Poorooshasb and Meyerhof [23] established a load versus settlement relationship for stone column stabilized soft clay after analyzing the correlation between stress ratio, axial stain, volumetric strain and axial strain. Fattah et al. [11] conducted large-scale experimental tests on uncased and encased stone columns on embankment models. The models were prepared with different length-to-diameter ratios (i.e. $L / D=6$ ), the spacing between the columns. It was observed that the encasement of stone columns significantly enhances the bearing capacity of reinforced soft clay and reduces the settlement. Similarly, reducing the spacing between columns resulted improved bearing ratio for a given embankment. The maximum bearing improvement ratio was obtained for the current study with stone columns at $\mathrm{S}=2.5 \mathrm{D}$.

Bora and Dash [10] conducted experimental study on soft clay reinforced with the both single and group stone columns to investigate the stress-displacement behavior of granular columns and establish correlation between strength and bearing capacity of improved ground.

Consolidated Undrained Triaxial test under isotropic condition was conducted by Najjar et al. [21] on clay specimen with single sand column having $44 \%$ relative density and area replacement ratio less than $18 \%$. It was observed that young modulus increased due to reduction of express pore-water pressure during shearing

Meshkinghalam et al. [17] reported that the stone columns can be a significant ground improvement method for reduction of settlement and liquefaction of sandy soils. The group effect of the stone column was studied and concluded that the maximum performance of the stone column can be obtained with the center to center spacing between 2.5 and 3.5. Also, the drainage process can be accelerated with the installation of stone columns.

$\mathrm{Ng}$ [22] conducted three-dimensional numerical modeling of stone columns to determine the bearing capacity of a single stone in soft soil and concluded that bearing capacity of the stone column was influenced by friction angle of the column and surrounding soil. The combination of bulging and punching failure was reported in a single column. A relationship was developed to predict the ultimate bearing capacity of a single stone column. 
The current paper describes the small-scale modeling of sand column treated soft soil in the laboratory by varying different parameters such as shear strength of soft soil, length to diameter (L/D) ratio of the sand column, and spacing to diameter $(\mathrm{S} / \mathrm{D})$ ratio, in case of group columns. The experimental results are thereafter compared with finite element analysis results which were obtained using finite element tool PLAXIS 2D. The purpose of the study was to verify the behavior of sand columns in soft soil and assess the changes in the ultimate load carrying capacity of the composite ground. Various methods have been adopted to overcome the challenge among which inclusion of granular columns/stone columns is found be an effective technique for increasing the drainage properties of clayey soils and ultimately reducing settlement and enhancing the load carrying capacity of the composite ground. Most of the studies were conducted on stone columns with material size more than $4 \mathrm{~mm}$, which gave a significant improvement in bearing capacity of the composite ground. In this study, backfill material that was used for the column's construction is fine and have a size of less than $4 \mathrm{~mm}$ (i.e. course sand). However, very little research and theories are available in the literature for sand replacement column to treat the clayey soil. Also, this work of this paper provides a practical guide for practicing geotechnical design engineers to establish an optimum and costeffective sand columns inclusion scheme to achieve the required target of soil improvement and better assess the improvement factors.

\section{Experimental setup} Test program

A series of model tests of treated soil with sand column was performed in the laboratory to study the efficiency of these columns in improving the load carrying capacity of the soil. The steel molds used for experimentation had the following dimensions; height $=360 \mathrm{~mm}$, internal diameter $=300 \mathrm{~mm}$, wall thickness $=6 \mathrm{~mm}$ and were locally assembled. Load tests were carried out in two steps; first on untreated soil and in the second stage on treated soil in a Compression Testing Machine.

\section{Properties of materials}

The materials used in this study were clay and sand. The clayey soil was collected from Jahangira district Sawabi, province of KPK, Pakistan. The soil was then pulverized in the laboratory to conduct different tests to obtain various engineering properties like moisture content, grain size distribution, Atterberg's limits, unconfined compressive strength, and Proctor compaction tests. The results are summarized in Table 1. Locally available sand was used as backfill material in sand columns. The sand was thoroughly washed and oven dried, sieve analysis was performed and the angle of internal friction was found using direct shear test. The maximum and minimum dry density was found out to be $14.77 \mathrm{kN} / \mathrm{m}^{3}$ and $13.98 \mathrm{kN} / \mathrm{m}^{3}$. The physical properties of sand are summarized in Table 2. The gradation curve for virgin clay and column material is illustrated in Fig. 1.

\section{Preparation of clay bed}

All the compression tests were performed on soft clay samples at various undrained shear strengths of $54 \mathrm{kPa}, 32 \mathrm{kPa}$, and $14 \mathrm{kPa}$. Before the preparation of clay bed, unconfined compression tests were conducted on a sample of $40 \mathrm{~mm}$ diameter and $80 \mathrm{~mm}$ 


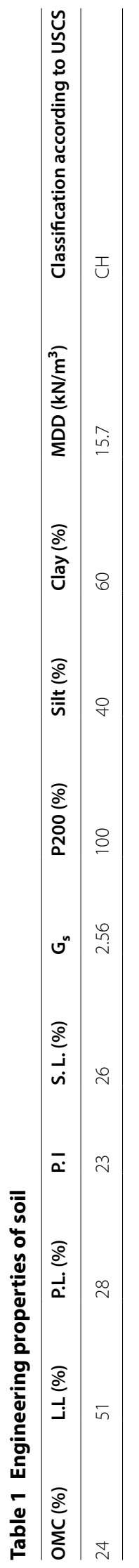


Table 2 Physical properties of column material

\begin{tabular}{lccllll}
\hline Properties & $\mathbf{G}_{\mathbf{s}}$ & $\boldsymbol{\Phi}_{\mathbf{s}}$ & $\boldsymbol{V}_{\max }\left(\mathbf{k N} / \mathbf{m}^{\mathbf{3}}\right)$ & $\boldsymbol{V}_{\min }\left(\mathbf{k N} / \mathbf{m}^{\mathbf{3}}\right)$ & Fineness modulus & Water absorption (\%) \\
\hline Values & 2.7 & $31^{\circ}$ & 14.77 & 13.98 & 2.018 & 0.51
\end{tabular}
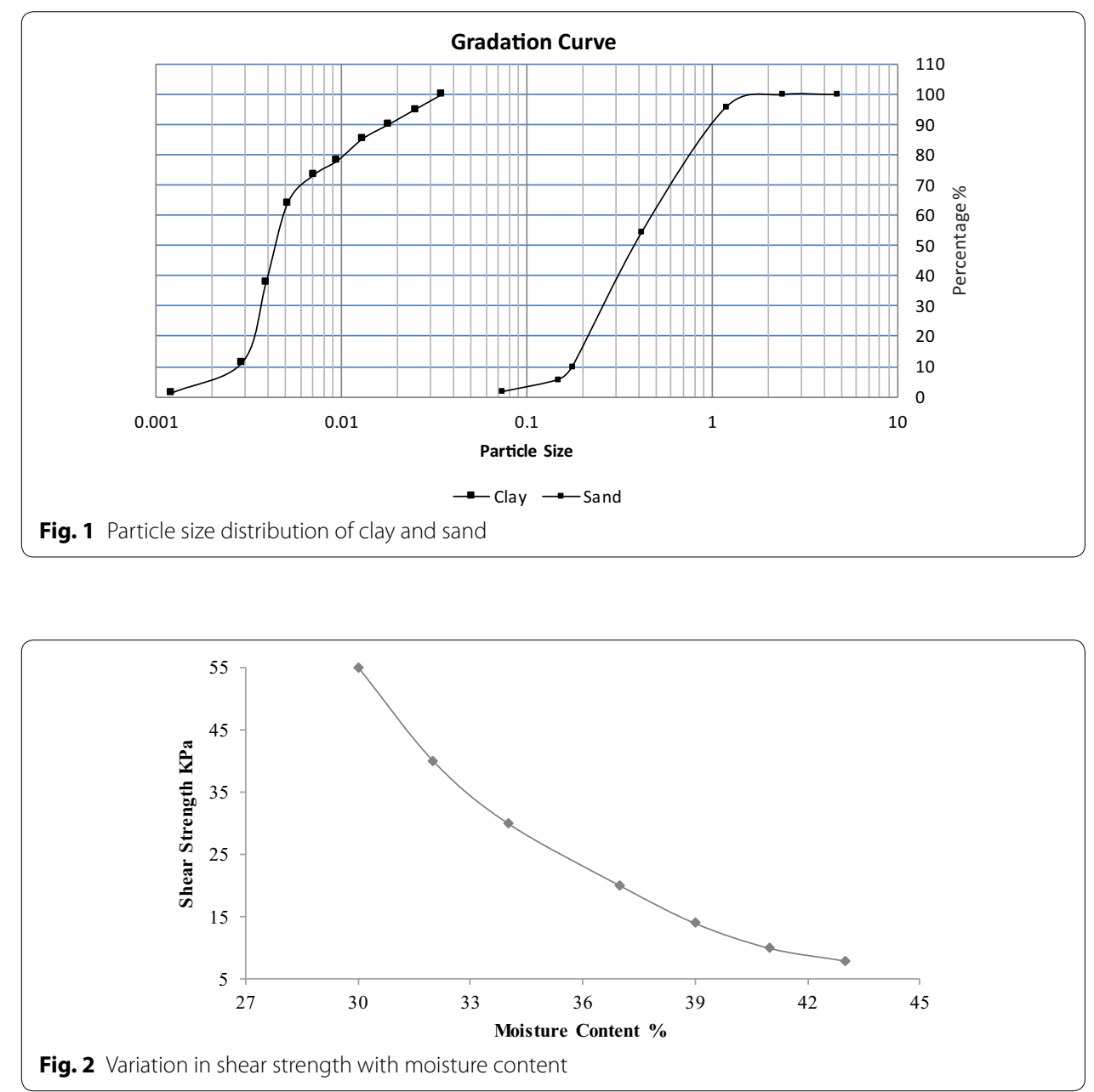

height. A relationship was developed between moisture content and unconfined compressive strength. Figure 2 illustrates the change in shear strength of clay with the addition of moisture content. Moisture contents corresponding to desired shear strength were found to be $31 \%, 35 \%$ and $39 \%$. In order to prepare clay bed, oven dried clay sample was used and then the required an amount of water was added to soil to obtain desired shear strength. In order to minimize the side friction among the clay and tank walls, the inner sides of steel tank were lubricated with oil. The soil was filled in the container in six layers, each layer $50 \mathrm{~mm}$ thick after compaction. The soil was filled in the container up to a total height of $300 \mathrm{~mm}$. Uniform compaction energy of $60,420 \mathrm{~kg}-\mathrm{m} / \mathrm{m}^{3}$ was applied on the surface to each sample, as in the case of Standard Proctor Test. Each layer was compacted with a tamper of $10 \mathrm{~kg}$ dropped from a height of $300 \mathrm{~mm}$ and given 70 blows. The samples were compacted so that air voids can be removed to achieve maximum density. 


\section{Construction of sand columns}

After the preparation of the soil bed, a replacement method was used to install the sand columns (SC). SC was installed using a seamless steel pipe opened from both ends and having an outer diameter of $37 \mathrm{~mm}$ and the inner diameter of $35 \mathrm{~mm}$. Steel Pipe is slightly pushed down into the clay at the center of the clay bed up to the anticipated depth. In order to avoid disturbance of surrounding soil and easy penetration, steel pipe was slightly greased on the outer surface. To avoid suction, a maximum height of $50 \mathrm{~mm}$ of soil was removed at a time. After removing the soil, the column material was fed into the hole from the top in layers of $50 \mathrm{~mm}$ each. After pouring backfill material, compaction was made to achieve uniform density. Compaction was applied with a $1.25 \mathrm{~kg}$ circular steel tamper with 15 blows of $100 \mathrm{~mm}$ drop to each layer. Care was taken during the compaction to ensure that it did not create any disturbance in the surrounding soft clay by bulging laterally. The procedure was repeated until the column is completed to the required heights of $\mathrm{L} / \mathrm{D}=4,5.5$ and 7 . After the installation of the column, the top surface of the container was covered with a plastic sheet for 4 days as the curing period to ensure uniform moisture. After 4 days compression load test was carried out on each model. Construction of the sand column is illustrated in Fig. 3a-f.

\section{Test procedure}

After preparation of the model, the load-deformation behavior was studied by applying vertical load on the surface of untreated as well as treated soil in a compression chamber. A 100-mm thick steel plate with $200 \mathrm{~mm}$ diameter was placed at the center of steel container to transfer the uniform load on the soil. Strain gauges were attached to the upper plate to constantly monitor the settlement. The load was applied at a constant loading rate of $0.025 \mathrm{MN} / \mathrm{min}$. The load was applied continuously until a settlement of $30 \mathrm{~mm}$ was achieved. The sample was extracted from the mold and soil surrounding the column

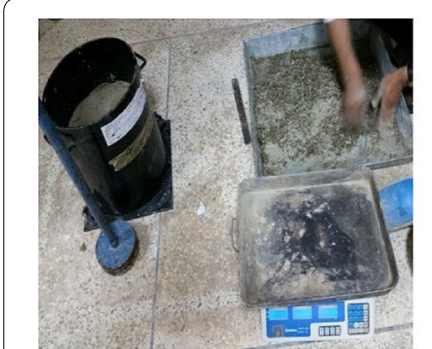

a

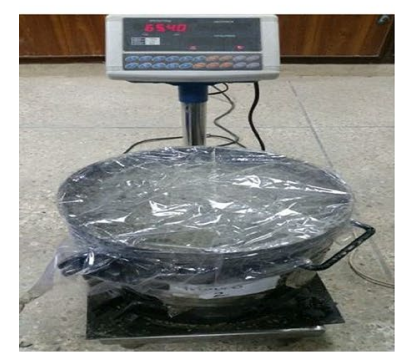

d

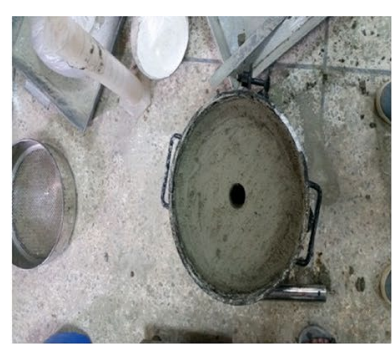

b

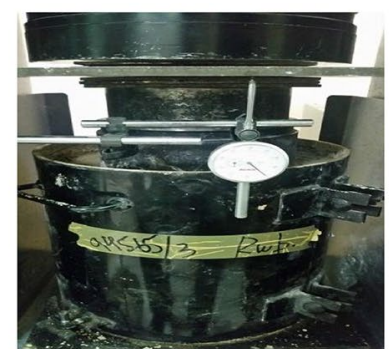

e

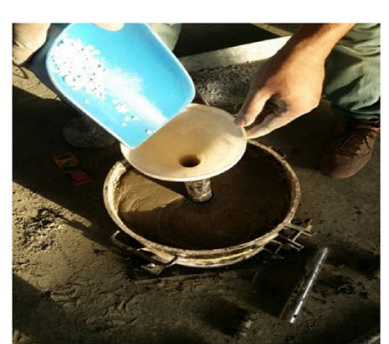

c

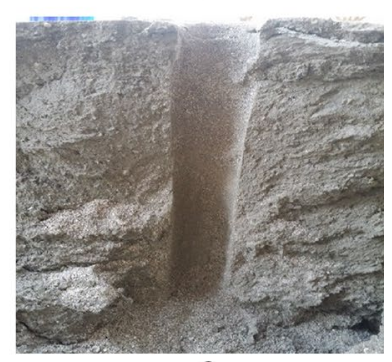

f

Fig. 3 a Mixing and compacting soil. b Borehole for column. c Pouring column material. d Model wrapped for curing. e Model testing. $\mathbf{f}$ Failure pattern of composite model 
was removed carefully to observe the failure pattern of the column. Figure 4 shows the typical test arrangement for loading on equivalent entire area and column area. Loading was applied on single and group columns with $200 \mathrm{~mm}$ diameter steel plate while total size (diameter) of steel tank is $300 \mathrm{~mm}$. Therefore, $3 \times \mathrm{D}$ distance was maintained between loading plate and sand column, in case of group column, to avoid frictional effects of steel tank's walls. The stiffness of improved ground was determined through the loading tests on equivalent entire area whereas, the axial capacity of the sand column was determined by applying load tests on column area alone.

\section{Numerical modeling using finite element analysis}

Finite element analysis using PLAXIS 2D was carried out on models of untreated and sand column treated soil model. The soil is modeled in axisymmetric condition using Mohr's Coulomb criterion. An undrained condition is anticipated for clay whereas, the drained condition is assumed for the sand column. The analysis parameters for sand and soft clay used in PLAXIS is shown in Table 3 and geometry for soil models is shown in Table 4.

Finite element analysis using PLAXIS-2D is carried on untreated and sand column treated soil model. The soil is modeled in axisymmetric condition using Mohr's Coulomb criterion. An undrained condition is assumed for clay whereas, the drained condition is assumed for sand columns. The analysis parameters for sand column material and soft clay used in PLAXIS are shown in Table 2 and geometry for soil models is shown in Table 3. The sand columns were modeled in the PLAXIS 2D using unit cell concept (axisymmetric), as illustrated in Fig. 5a, b. Along the periphery of the steel tank, at the interface between the soil and steel tank, the radial deformation was restricted, while downward movement (settlement) is allowed and at bottom of tank both radial and vertical deformation is restricted. These conditions were applied to all model using horizontal fixities, vertical fixities, and total fixities, respectively. At the interface between the sand column and clay, no interface element was used because generally, sand columns and granular columns fail in radial bulging instead of shear failure. Furthermore, the interface between soil and sand column is a mixed zone area where shear strength

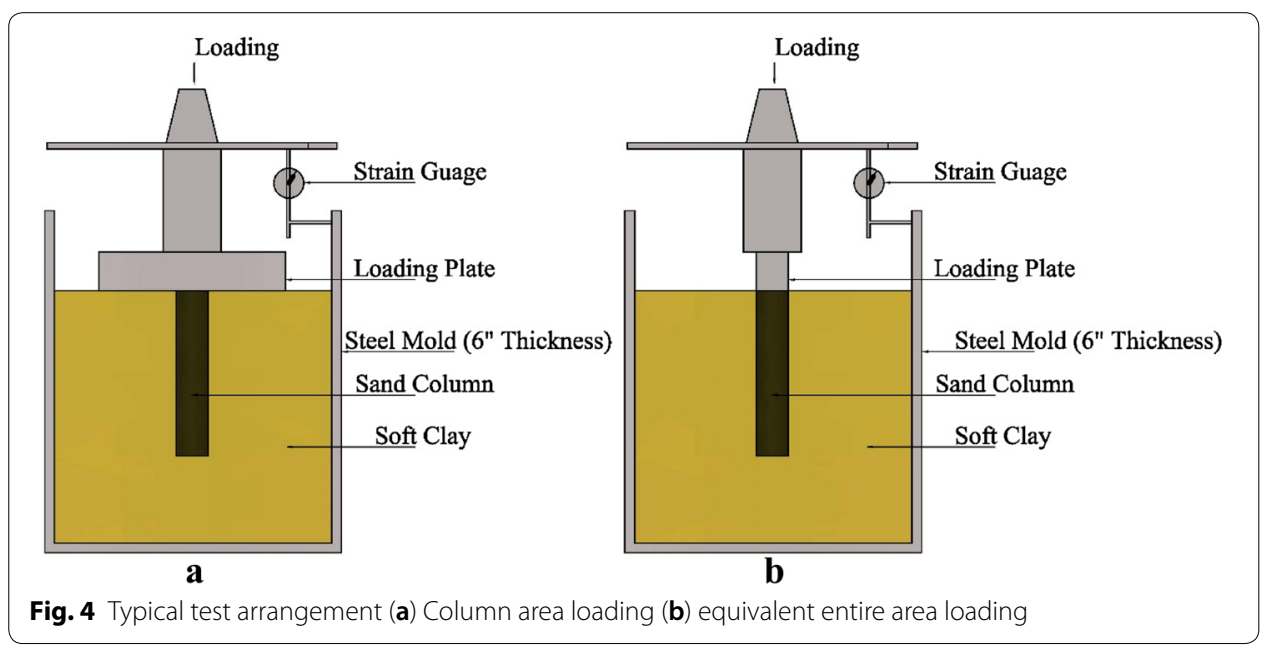




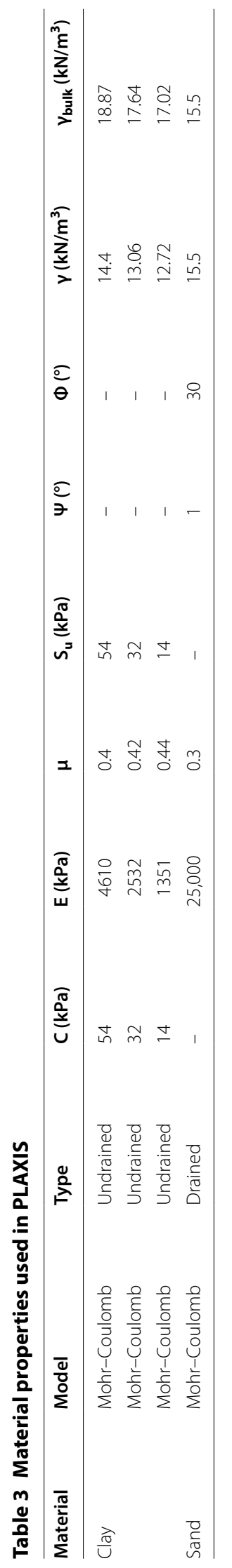


Table 4 Geometry data of different sand columns

\begin{tabular}{lllllll}
\hline Model & $\begin{array}{l}\text { Shear strength } \\
\text { of soil } \mathbf{S}_{\mathbf{u}}(\mathbf{k P a})\end{array}$ & Height $(\mathbf{m m})$ & $\begin{array}{l}\text { Dia. of soil } \\
\text { sample } \mathbf{D}_{\mathbf{s}} \\
(\mathbf{m m})\end{array}$ & $\begin{array}{l}\text { Dia. of sand } \\
\text { column } \mathbf{D}_{\mathbf{c}} \\
(\mathbf{m m})\end{array}$ & $\begin{array}{l}\text { Length of sand } \\
\text { column } \mathrm{L}_{\mathbf{s}}(\mathbf{m m})\end{array}$ & $\mathrm{L}_{\mathbf{s}} / \mathbf{D}_{\mathbf{c}}$ \\
\hline Model 1 & 54 & 300 & 300 & 37 & 150 & 4 \\
Model 2 & 32 & 300 & 300 & 37 & 200 & 5.5 \\
Model 3 & 14 & 300 & 300 & 37 & 250 & 7 \\
Model 4 & 32 & 300 & 300 & 37 & 200 & 5.5 \\
Model 5 & 32 & 300 & 300 & 37 & 250 & 5.5 \\
\hline
\end{tabular}

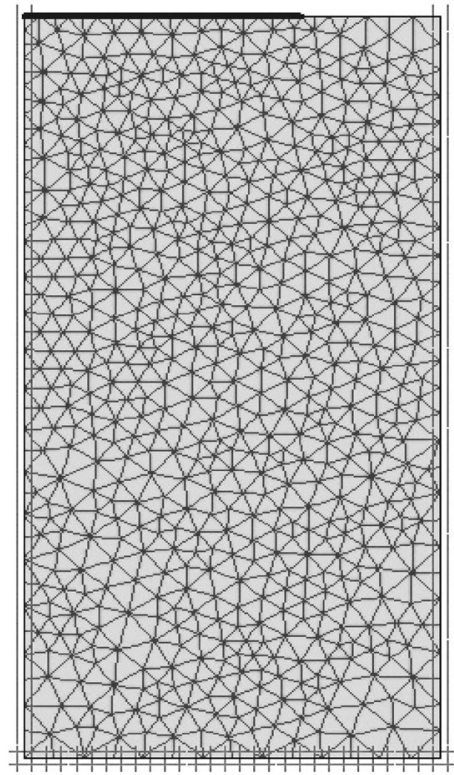

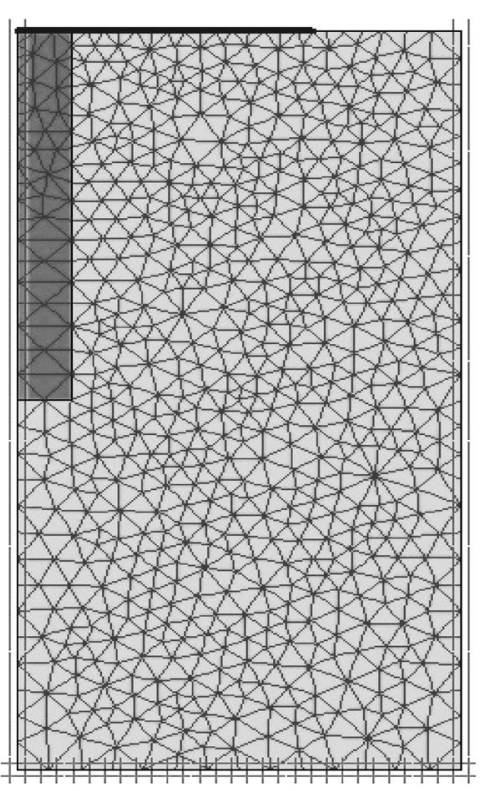

b

Fig. 5 FM Mesh (axisymmetric) a without sand column, b with sand column

properties vary depending upon the method used for the installation of sand columns. Therefore, under mix soil conditions, no interface element is assigned. Mitchell and Huber [18] and Ambily and Gandhi [3] also performed a similar kind of finite-element analysis for a stone column without an interface element.

\section{Results and discussions}

\section{Experimental results}

\section{Influence of shear strength on the efficiency of the sand column}

In order to determine the behavior of sand columns, the load tests were conducted on untreated and treated soil samples by varying different parameters like shear strength of soil, length to diameter ratio of sand columns (L/D), and loading conditions (entire area loaded and column alone loaded). Figure 6 illustrates the load-settlement curves of treated and untreated soil at $\mathrm{L} / \mathrm{D}=4$ and shear strength of $54 \mathrm{kPa}, 32 \mathrm{kPa}$, and $14 \mathrm{kPa}$, respectively. The load-bearing capacity for $30 \mathrm{~mm}$ displacement of sand columns treated soil samples increased significantly as compared to the untreated sample. It was perceived that ultimate load carrying capacity of the treated sample increased by $37 \%$ for 


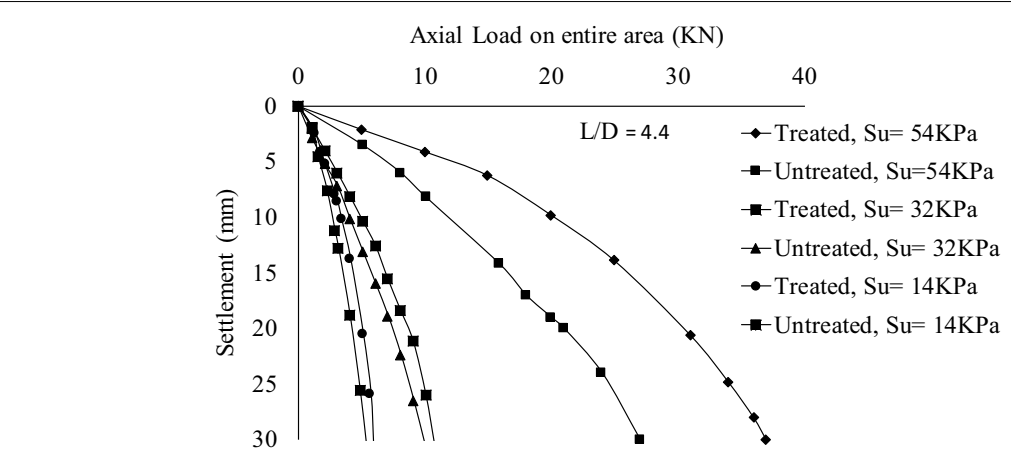

Fig. 6 Effect of sand column on clayey soil of different shear strength

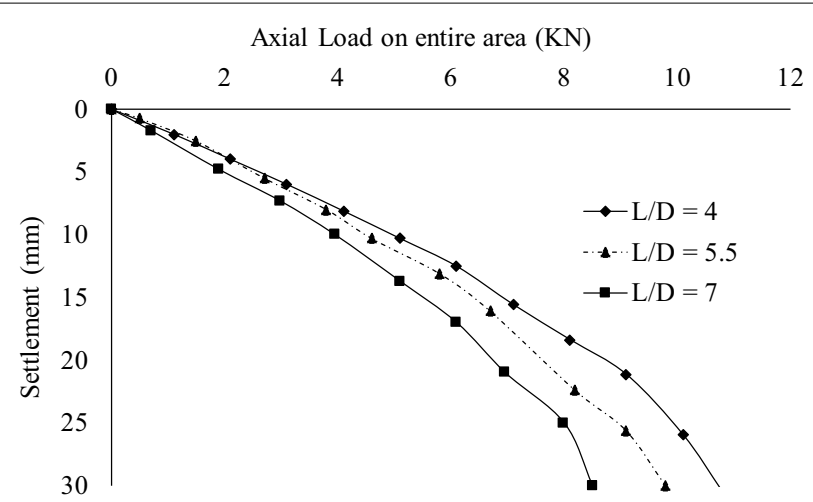

Fig. 7 Effect of L/D of sand column on clayey soil at $32 \mathrm{kPa}$ shear strength

same settlement at $54 \mathrm{kPa}$ shear strength whereas, $8 \%$ and $6 \%$ increment was observed at $32 \mathrm{kPa}$ and $14 \mathrm{kPa}$ shear strength of soil, respectively. This shows that sand columns are more operative in soft soils with relatively higher shear strength whereas, less effective in week soils. A similar trend was observed by Ambily and Gandhi [3], and Asaoka et al. [4] in their findings of model tests on granular columns. The behavior of single column simulates the field performance of an interior column belonging to a group of columns.

\section{Effect of column length on soil}

Figure 7 depicts the effect of length to diameter ratio (L/D) of sand columns on clayey soil. It is observed that load carrying capacity is maximum at $\mathrm{L} / \mathrm{D}=4$, whereas, it decreases as L/D increases. A critical column length of 4 to 6 times the diameter of column (D) was identified by different researchers beyond which no significant increase in load carrying capacity was observed. Fattah et al. [11], Ambily and Gandhi [3].

\section{Influence of group sand column}

Figure 8 shows the effect of group sand columns on soft soil. The group columns are installed in a triangular pattern with spacing to diameter ratio (S/D) of 2 and 3. In Fig. 8, the comparison of untreated soil, soil treated with single column and soil treated with group columns is made. It is observed that settlement reduces as the S/D reduces at 


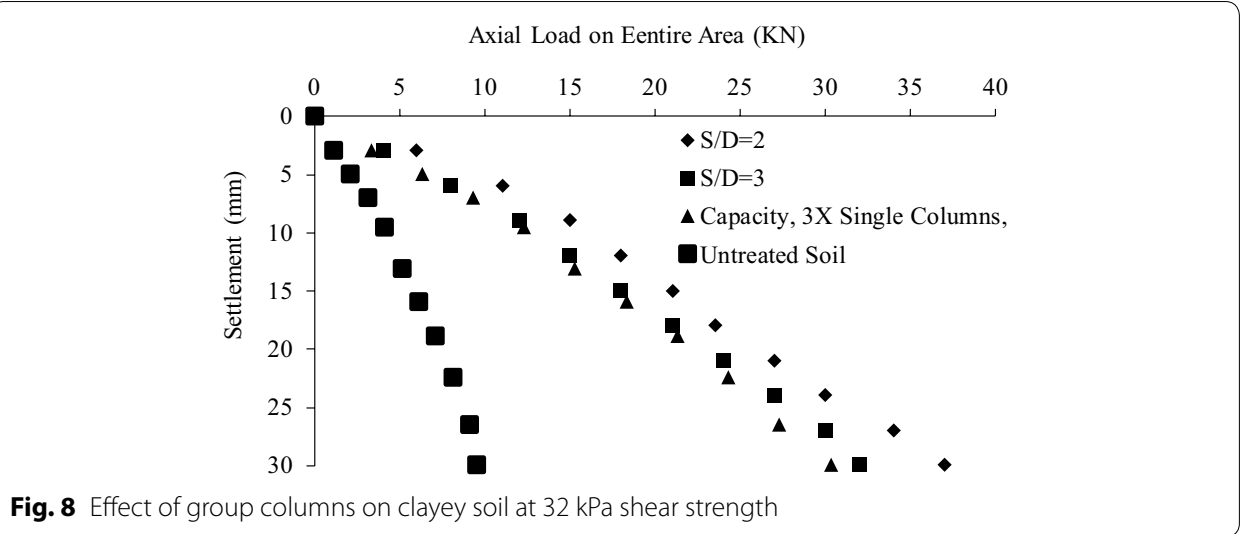

Fig. 8 Effect of group columns on clayey soil at $32 \mathrm{kPa}$ shear strength

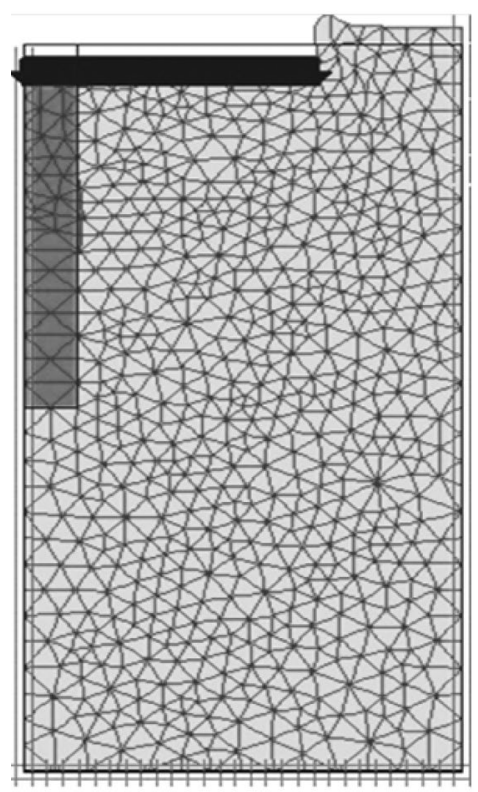

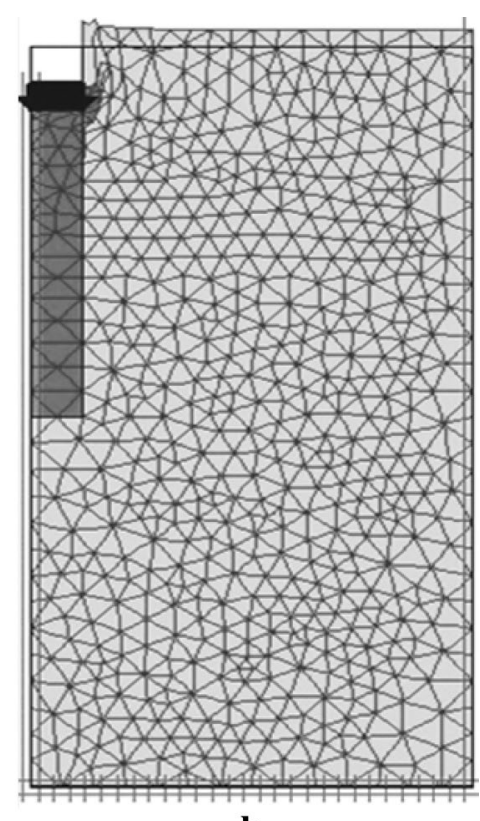

b

Fig. 9 FM mesh (axisymmetric) a entire area loaded, b column area lone loaded

same loading which means that Load carrying capacity of the sample with $S / D=2$ is higher as compared to that of $S / D=3$. Ambily and Gandhi [3] investigated the group effect of granular columns and reported that when the spacing between the columns increases, the axial capacity of the column decreases and hence the settlement increases to $\mathrm{S} / \mathrm{D}=3$, after which no significant change is recorded.

\section{Finite element analysis}

\section{Entire area loaded}

Finite element analysis using PLAXIS 2D was carried out on models of untreated soil and sand column treated soil to investigate the performance of sand columns in clayey soil. The sand columns were modeled in an axisymmetric pattern in PLAXIS. Figure 9a, $\mathrm{b}$ and illustrates the typical deformed mesh of treated samples for equivalent entire area 


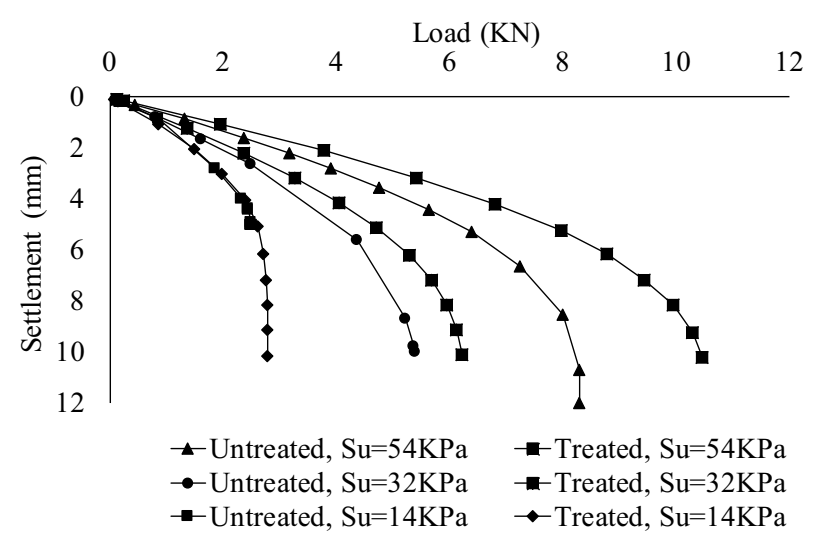

Fig. 10 FEM analysis of sand columns on clayey soil of different shear strength

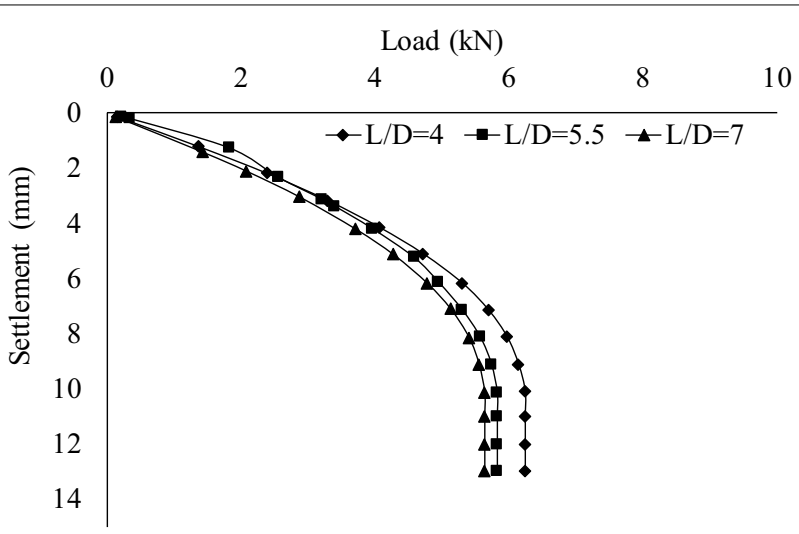

Fig. 11 FEM analysis of sand columns on clayey soil at varying L/D

loading and column area alone loadings. Bulging of the sand column near the top surface, where loading is directed applied, was observed in case of column alone area loading and an equal settlement was noted in case of entire area loading. Figure 10 illustrates the FEM results of sand column treated soil for $\mathrm{L} / \mathrm{D}=4$ and shear strength of $54 \mathrm{kPa}$, $32 \mathrm{kPa}$, and $14 \mathrm{kPa}$. Figure 11 represents the FEA results of sand column treated composite ground with different $\mathrm{L} / \mathrm{D}$ ratios at shear strength of $32 \mathrm{kPa}$. It can be observed that at higher L/D (i.e. 7), the load carrying capacity of composite ground decreases as compared to the low L/D ratio (i.e. 4). Similar behavior was observed in the experimental test as presented in Fig. 7. Figure 12 presents the variation in stiffness improvement factor with a variation of shear strength of clay in both experimental and numerical analysis. Stiffness improvement factor is calculated as settlement of improved ground divided by the settlement of untreated ground.

\section{Column alone loaded}

Sand columns or stone columns may fail in bulging. Previous studies show that the granular columns may fail either in bulging or punching when subjected to axial as well as distributed loads Barksdale and Bachus [6]. The failure modes of sand column subjected to uniformly distributed load is shown in Fig. 13. The bulging depth may vary from 2 


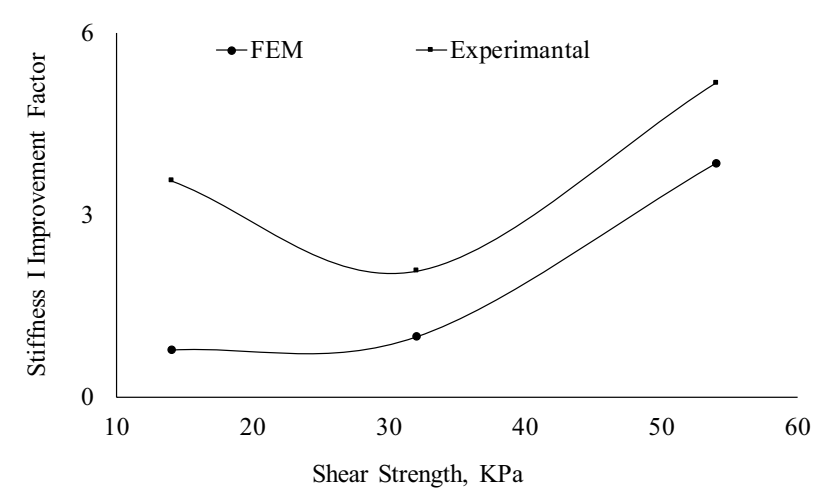

Fig. 12 Stiffness improvement factor

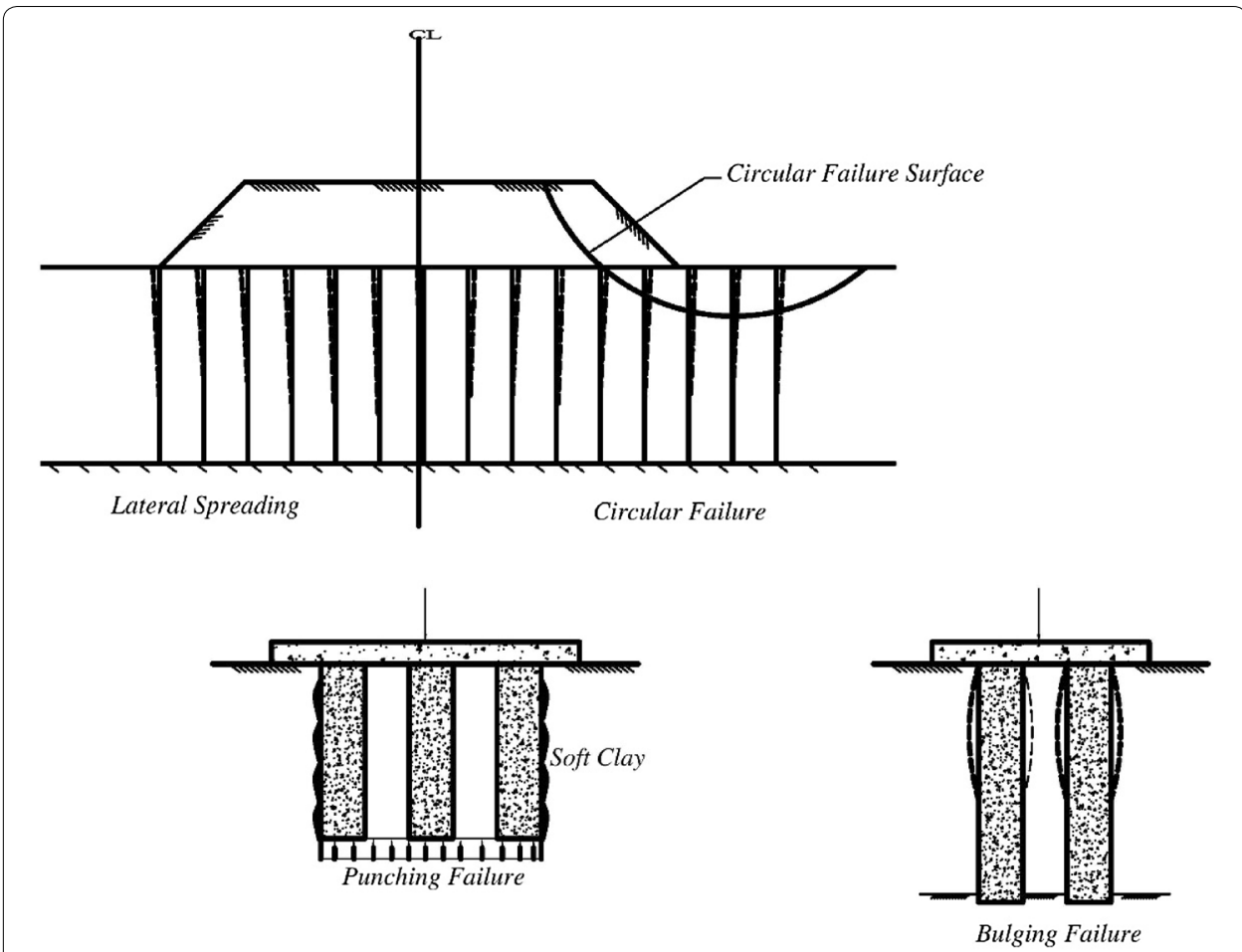

Fig. 13 Failure modes of sand columns under wide flexible loading

to 3 times the diameter of the column. Because of bulging, the lateral stresses on cohesive soil increases resulting in providing the additional confinement to the column. As a result, a balance condition occurs and vertical displacement decreases as compared to untreated soil. Figure 14 shows the bulging of the sand column. The bulging of the sand column is observed at the upper portion of the column and gradually increasing up to the depth of 1.5 to 2 times the diameter of the sand column. The maximum bulging occurs at the upper portion of the column where axial load is maximum and with depth, the bulging decreases due to less effect of stress on the column. It is also noted that the bulging effect becomes zero at full depth of the column. Figure 15 present the typical relationship of settlement and axial capacity of the sand column at different shear 

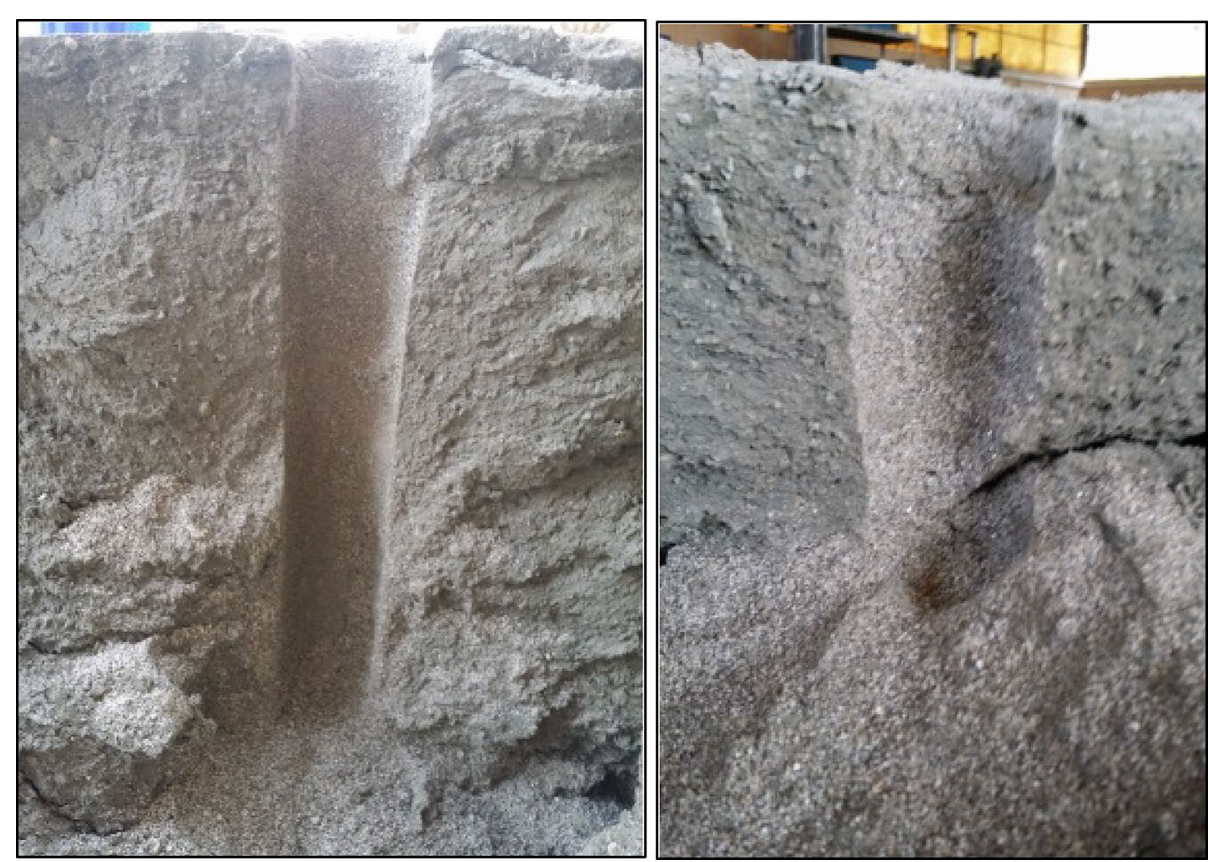

Fig. 14 Bulging of sand columns
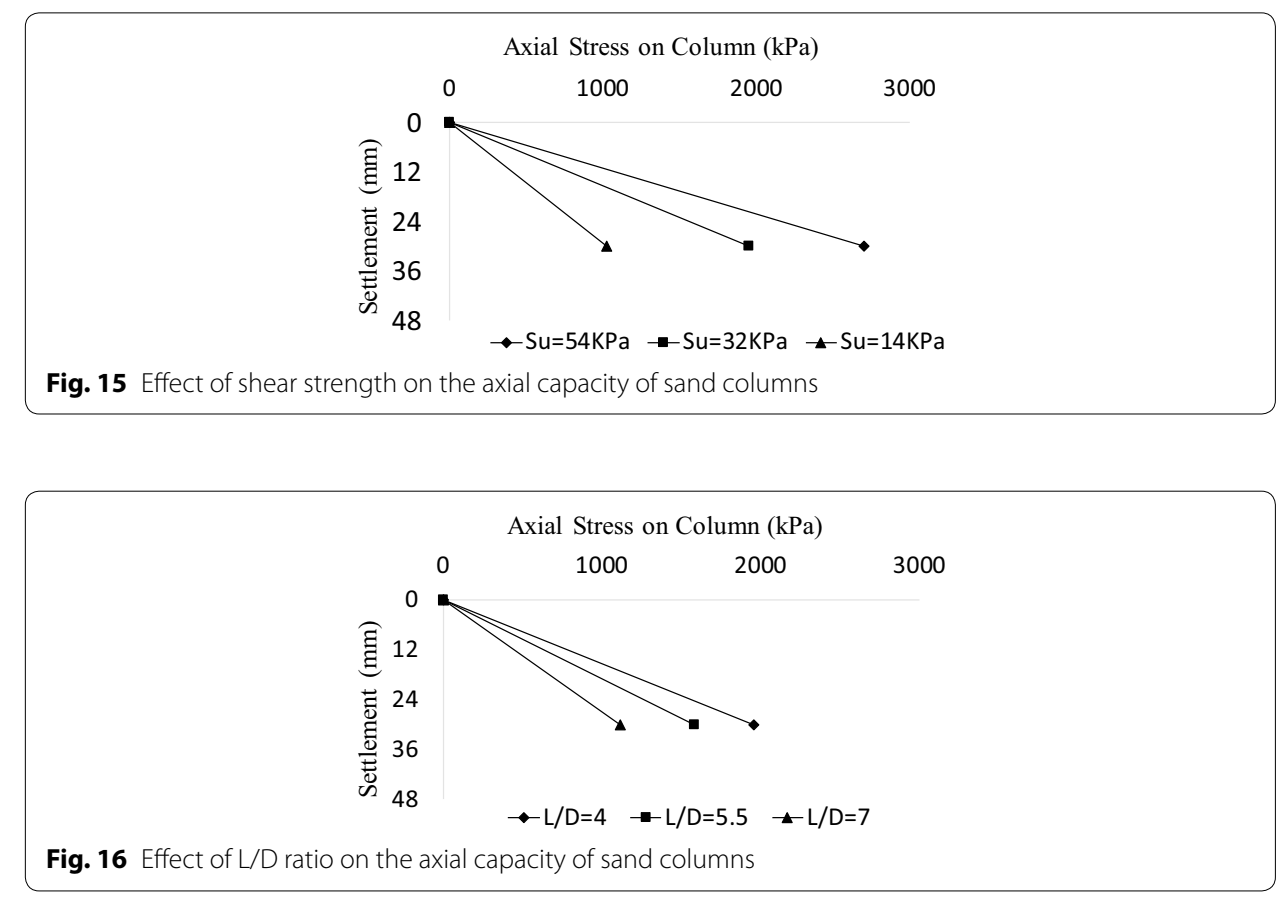

strength. The shear strength of clay significantly affects the axial capacity of the sand column. The sand column showed the maximum axial capacity at relatively stiff clay i.e. at $\mathrm{S}_{\mathrm{u}}=54 \mathrm{kPa}$ and minimum capacity at comparatively soft clay i.e. at $\mathrm{S}_{\mathrm{u}}=14 \mathrm{kPa}$.

Figure 16 illustrates the axial capacity of the sand column against the different length to diameter ratios. It was observed that with higher L/D ratio the axial capacity of sand 
column decreases due to the increase in slenderness of sand columns. The similar behavior was observed during the entire area loading on treated samples.

\section{Conclusions}

Natural on situ- soils are sometimes not favorable for the construction of engineered structures; therefore, soils need to be improved/reinforced. Sand column or Sand Compaction Piles method is a ground improvement technique which is widely used in worldwide. A detailed experimental and finite element-based study is conducted in order to investigate the effect of sand columns in clayey soils. After conducting the detailed experimental and numerical analysis, the succeeding conclusions are outlined as follows;

1. The shear strength of clayey soils plays a significant role in influencing the Sand columns or sand compaction piles. The behavior of sand columns in clayey soil with different shear strength (i.e. $\mathrm{S}_{\mathrm{u}}=54 \mathrm{kPa}, 32 \mathrm{kPa}$, and $14 \mathrm{kPa}$ ) is investigated in this study. It was observed that sand column is more effective in relatively higher shear strength as compared to week soil. Whereas the little increment in ultimate loading capacity of the composite ground is noted in shear strength of $32 \mathrm{kPa}$ and no significant improvement is observed at $\mathrm{S}_{\mathrm{u}}=14 \mathrm{kPa}$.

2. The consequence of length to diameter ratio is also investigated. The maximum strength increment is achieved at $\mathrm{L} / \mathrm{D}=4$. While increasing the $\mathrm{L} / \mathrm{D}$ ratio, the loading capacity decreases due to the bulging of the sand column in the composite ground. Therefore, the critical length for partially penetrating column was perceived to be 4 times the diameter of the sand column.

3. The influence of sand group columns is also determined; group efficiency is calculated by varying the spacing among the columns. As the spacing among the columns increases the ultimate load carrying capacity decreases. The group effect reduces as spacing increases.

4. The single sand column tests with equivalent area loaded are well comparable with the group column tests. The single sand column will simulate the practical behavior for an interior sand column when large numbers of columns are subjected to uniform loading.

5. The bulging of sand columns is observed in the top region of the column where axial stress is maximum and bulging depth remain constant till the 1.5 times the diameter of the sand column when column alone is loaded. However, in case of the entire area loaded, no bulging occurs in sand column. The bearing capacity failure is observed while the entire area is loaded.

\section{Authors' contributions}

SN: The entire study was conducted by him. MSF: carried out the literature studes in addition to the finite element analysis using the PLAXIS. SI: He is an expert from a geotechnical firm who guide and supervise the numerical modeling using PLAXIS and helped in drafting the manuscript. SM: He is the major supervisor of the entire study. All authors read and approved the final manuscript. 


\author{
Author details \\ ${ }^{1}$ Department of Geotechnical Engineering, National University of Sciences and Technology (NUST), Islamabad, Pakistan. \\ 2 Ammico Contracting Co. W.L.L., Doha, Qatar.
}

Received: 22 November 2018 Accepted: 2 October 2019

Published online: 18 October 2019

\title{
References
}

1. Aboshi H, Mizuno Y, Kuwabara M (1991) The present state of sand compaction pile in Japan. Deep Foundation Improvements: design, construction, and testing. ASTM International, West Conshohocken. https://doi.org/10.1520/ STP25049S

2. Alamgir M, Miura N, Poorooshasb H, Madhav M (1996) Deformation analysis of soft ground reinforced by columnar inclusions. Comput Geotech 18(4):267-290. https://doi.org/10.1016/0266-352X(95)00034-8

3. Ambily A, Gandhi SR (2007) Behavior of stone columns based on experimental and FEM analysis. J Geotech Geoenviron Eng 133(4):405-415. https://doi.org/10.1061/(ASCE)1090-0241(2007)133:4(405)

4. Asaoka A, Kodaka T, Nozu M (1994) Undrained shear strength of clay improved with sand compaction piles. Soils Found 34(4):23-32. https://doi.org/10.3208/sandf1972.34.4_23

5. Ayadat T, Hanna AM (2005) Encapsulated stone columns as a soil improvement technique for collapsible soil. Proc Inst Civil Eng-Ground Improv 9(4):137-147

6. Barksdale RD, Bachus RC (1983) Design and construction of stone columns. Federal Highway Administration

7. Baumann V, Bauer G (1974) The performance of foundations on various soils stabilized by the vibro-compaction method. Can Geotech J 11(4):509-530. https://doi.org/10.1139/t74-056

8. Black J, Sivakumar V, Madhav M, McCabe B (2006) An improved experimental test set-up to study the performance of granular columns. Geotech Test J 29(3):193-199. https://doi.org/10.1520/GTJ14195

9. Bouckovalas G, Giannaros C (2000) An experimental study on model stone columns. Soils Found 40(6):11-22. https ://doi.org/10.3208/sandf.40.6_11

10. Dash SK, Bora MC (2013) Influence of geosynthetic encasement on the performance of stone columns floating in soft clay. Can Geotech J 50(7):754-765

11. Fattah MY, Al-Neami MA, Al-Suhaily AS (2017) Estimation of bearing capacity of a floating group of stone columns. Eng Sci Technol Int J 20(3):1166-1172. https://doi.org/10.1016/j.jestch.2017.03.005

12. Gustaf Z, Bouassida M, Debats J (2007) Improved soft clay characteristics due to stone column installation. Comput Geotech 34(2):104-111. https://doi.org/10.1016/j.compgeo.2006.09.008

13. Juran I, Guermazi A (1988) Settlement response of soft soils reinforced by compacted sand columns. J Geotech Eng 114(8):930-943. https://doi.org/10.1061/(ASCE)0733-9410(1988)114:8(930)

14. Juran I, Riccobono O (1991) Reinforcing soft soils with artificially cemented compacted-sand columns. J Geotech Eng 117(7):1042-1060. https://doi.org/10.1061/(ASCE)0733-9410(1991)117:7(1042)

15. Kadhim ST, Fouad ZB (2018) Stability analysis of roadway embankments supported by stone columns with the presence of water table under short-term and long-term conditions. In: MATEC web of conferences. Vol. 162, p 01013. EDP Sciences. https://doi.org/10.1051/matecconf/201816201013

16. Killeen MM, McCabe BA (2014) Settlement performance of pad footings on soft clay supported by stone columns: a numerical study. Soils Found 54(4):760-776. https://doi.org/10.1016/j.sandf.2014.06.011

17. Meshkinghalam H, Hajialilue-Bonab M, Azar AK (2017) Numerical investigation of stone columns system for liquefaction and settlement diminution potential. Int J Geo-Eng 8(1):11. https://doi.org/10.1186/s40703-017-0047-x

18. Mitchell JK, Huber TR (1985) Performance of a stone column foundation. J Geotech Eng 111(2):205-223. https://doi. org/10.1061/(ASCE)0733-9410(1985)111:2(205)

19. Muir Wood D, Hu W, Nash D (2000) Group effects in stone column foundations: model tests. Geotechnique 50(6):689-698. https://doi.org/10.1680/geot.2000.50.6.689

20. Murugesan S, Rajagopal K (2006) Geosynthetic-encased stone columns: a numerical evaluation. Geotext Geomembr 24(6):349-358. https://doi.org/10.1016/j.geotexmem.2006.05.001

21. Najjar SS, Sadek S, Maakaroun T (2010) Effect of sand columns on the undrained load response of soft clays. J Geotech Geoenviron Eng 136(9):1263-1277. https://doi.org/10.1061/(ASCE)GT.1943-5606.0000328

22. Ng K (2018) Numerical study on bearing capacity of the single stone column. Int J Geo-Eng 9(1):9. https://doi. org/10.1186/s40703-018-0077-z

23. Poorooshasb H, Meyerhof $G$ (1997) Analysis of the behavior of stone columns and lime columns. Comput Geotech 20(1):47-70. https://doi.org/10.1016/S0266-352X(96)00013-4

24. Sexton B, McCabe B (2013) Numerical modeling of the improvements to primary and creep settlements offered by granular columns. Acta Geotech 8(4):447-464. https://doi.org/10.1007/s11440-012-0205-4

25. Sivakumar V, McKelvey D, Graham J, Hughes D (2004) Triaxial tests on model sand columns in clay. Can Geotech J 41(2):299-312. https://doi.org/10.1139/t03-097

26. Tan SA, Tjahyono S, Oo KK (2008) Simplified plane-strain modeling of the stone-column reinforced ground. J Geotech Geoenviron Eng 134(2):185-194. https://doi.org/10.1061/(ASCE)1090-0241(2008)134:2(185)

\section{Publisher's Note}

Springer Nature remains neutral with regard to jurisdictional claims in published maps and institutional affiliations. 